\title{
Simple cough as a cause of subcutaneous emphysema
}

\author{
Boudour Louai Khayer
}

Department of Emergency, Dubai Health Authority, Dubai, United Arab Emirates

\section{Correspondence to} Dr Boudour Louai Khayer, blkhayer@dha.gov.ae

Accepted 6 June 2014
CrossMark

To cite: Khayer BL. BMJ Case Rep Published online: [please include Day Month Year] doi:10.1136/bcr-2014205123

\section{DESCRIPTION}

This X-ray is of a healthy 3-year-old girl who presented with fever and cough for 2 days. She had been admitted in a private clinic and started on oral antibiotics for upper respiratory tract infection. On the second day of her symptoms her parents noticed swelling of the neck and upper chest and the child was brought to the emergency department.

On examination the girl was stable and not in respiratory distress. Subcutaneous emphysema was noticed clinically (by crepitus) and chest auscultation was normal.

Figure 1 is the chest X-ray on the day of admission showing vast subcutaneous and mediastinal emphysema.

The child was admitted for observation and stayed in the hospital for 2 days. She was discharged in good condition as her subcutaneous emphysema improved clinically and her chest X-ray after 2 days showed significant resolution of the emphysema (figure 2).

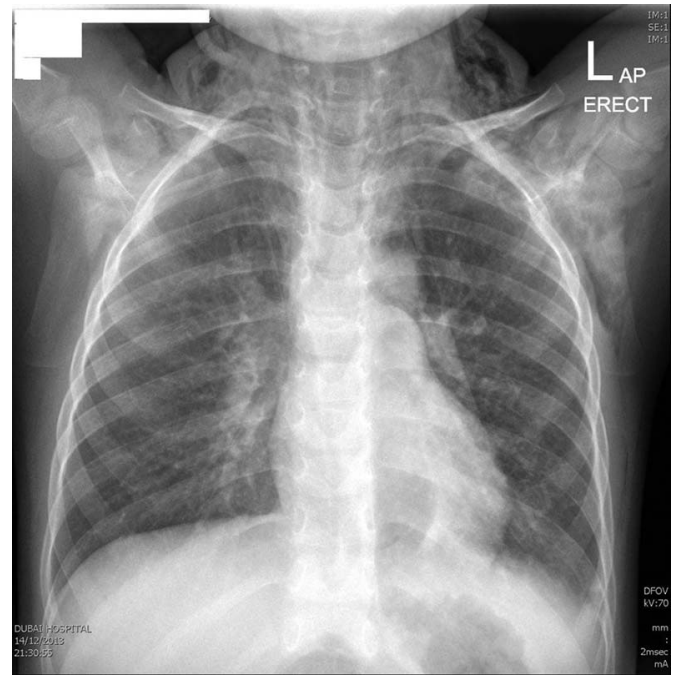

Figure 1 Showing vast subcutaneous and mediastinal emphysema on the day of admission.

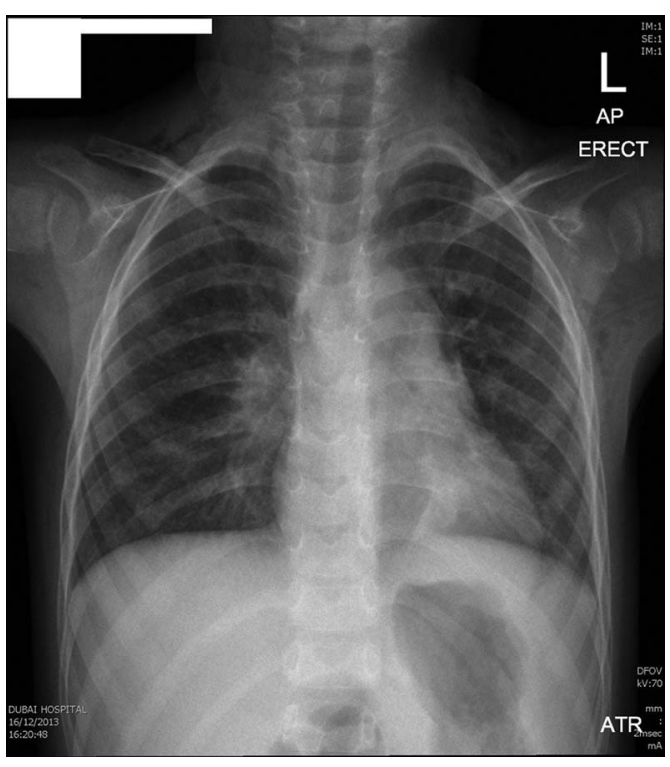

Figure 2 Showing significant resolution of emphysema after 2 days.

\section{Learning points}

- Subcutaneous emphysema could be a complication of a simple cough.

- When there is no serious cause of emphysema, the symptoms are minimal even with a vast one and the resolution is fast.

Competing interests None.

Patient consent Obtained.

Provenance and peer review Not commissioned; externally peer reviewed.

Copyright 2014 BMJ Publishing Group. All rights reserved. For permission to reuse any of this content visit

http://group.bmj.com/group/rights-licensing/permissions.

BMJ Case Report Fellows may re-use this article for personal use and teaching without any further permission.

Become a Fellow of BMJ Case Reports today and you can:

- Submit as many cases as you like

- Enjoy fast sympathetic peer review and rapid publication of accepted articles

- Access all the published articles

- Re-use any of the published material for personal use and teaching without further permission

For information on Institutional Fellowships contact consortiasales@bmjgroup.com

Visit casereports.bmj.com for more articles like this and to become a Fellow 